\title{
Phytoextraction potential of different grasses for the uptake of cadmium and lead from industrial wastewater
}

\author{
Sana Ullah ${ }^{* 1}$, Zafar Iqbal' ${ }^{1}$, Sajid Mahmood ${ }^{1}$, Kalsoom Akhtar ${ }^{2}$ and Rehmat Ali ${ }^{1}$ \\ ${ }^{1}$ Soil and Environmental Sciences Division, Nuclear Institute for Agriculture (NIA), Tandojam Tando Jam 70050, Sindh, \\ Pakistan \\ ${ }^{1}$ Soil and Environmental Sciences Division, Nuclear Institute for Agriculture and Biology (NIAB), Faisalabad 38000, \\ Pakistan \\ ${ }^{2}$ National Institute for Biotechnology and Genetic Engineering (NIBGE), Faisalabad 38000, Pakistan \\ [Received: June 03, 2019 Accepted: January 04, 2020 Published Online: March 21, 2020]
}

\begin{abstract}
Industrial wastewater contains a variety of contaminants like salts, organic carbon, and heavy metals. Among the heavy metals, cadmium $(\mathrm{Cd})$ and lead $(\mathrm{Pb})$ are considered highly toxic even at low concentration. These metals could enter the food chain through a process of phytoassimilation, hence, lethal for living beings. The present study aimed to investigate Cd and Pb phytoextraction in four grass species viz. Dhab (Desmostachya bipinnata), Sporobolus (Sporobolus arabicus), Kallar (Leptochloa fusca) and Para grass (Brachiaria mutica) from industrial wastewater. The grasses were grown hydroponically in plastic pots in industrial wastewater as growth medium under greenhouse conditions. The experiment trial was arranged following completely randomized design (CRD) with three replicates. Results showed that B. mutica had maximum shoot metal content $\left(\mathrm{Pb}=21, \mathrm{Cd}=0.66 \mathrm{mg} \mathrm{kg}^{-1}\right.$ dry matter $)$, shoot metal uptake $\left(\mathrm{Pb}=201.8, C d=6.39 \mu \mathrm{g}\right.$ plant $\left.^{-1}\right)$, translocation factor $(\mathrm{Pb}=0.73, \mathrm{Cd}=0.55)$, shoot dry matter $\left(28.8 \mathrm{~g} \mathrm{pot}^{-1}\right)$, and root dry matter $\left(4.2 \mathrm{~g} \mathrm{pot} \mathrm{pt}^{-1}\right)$. Root $\mathrm{Pb}$ concentration was highest in B. mutica followed by D. bipinnata and L. fusca. Whereas S. arabicus showed depressed growth, minimum shoot metal accumulation and uptake potential. Thereby among the tested grass species $B$. mutica could be suitable option to remediate industrial wastewater contaminated with moderate levels of $\mathrm{Pb}$ and $\mathrm{Cd}$.
\end{abstract}

Keywords: Metal uptake, para grass, kallar grass, dry biomass, metal concentration

\section{Introduction}

Heavy metals usually indicate environmentally bad metals which have higher atomic number, or atomic weight, density (3.5-7.0 $\mathrm{g} \mathrm{cm}^{-3}$ or above), properties of metallic substance at room temperature, and are extremely toxic for living organisms even at lower concentration (Duffus, 2002; Mitra, 2019). These metals include lead $(\mathrm{Pb})$, cadmium (Cd), chromium, nickel, arsenic and mercury which are well-known environmental contaminants due to their toxic nature, bioaccumulation and persistence in the environment (Latif et al., 2019; Ali et al., 2019). Heavy metal contamination distresses the environment and food security ultimately posing serious health concerns (Rai et al., 2019; Mushtaq et al., 2019). With rampant inflation in anthropogenic activities, the release of toxic metals into the environment is increasing day by day. According to an estimate, global annual release of $\mathrm{Pb}$ and $\mathrm{Cd}$ into the environment is 783,000 and 22,000 metric tons, respectively
(Singh et al, 2003). Wastewater from different sources (domestic, municipal and industries) plays significant role in release of heavy metals like $\mathrm{Pb}$ and $\mathrm{Cd}$. About 2 million tons of sewage sludge and effluents are polluting the world's water per day (Azizullah et al., 2011). Issue is more serious in developing countries due to improper treatment of domestic, municipal and industrial waste. Such as in India $24 \%$ of wastewater (industry and domestic) is treated, whereas in Pakistan only $2 \%$ of total sewerage or wastewater is treated properly (IWMI, 2003; Minhas and Samra, 2004; Majeed et al., 2018). Wastewater released from different industries contains a variety of toxic metals such as $\mathrm{Pb}, \mathrm{Cd}$, chromium and arsenic (Rehman et al., 2018, 2019; Hussain et al. 2019; Afzal et al. 2019). Use of industrial effluents/wastewater for cultivation of crops has created the problem of heavy metal contamination in soil (Hussain et al., 2019). Moreover, in developing countries, like Pakistan, shortage of good quality irrigation water also urges the farmers to use wastewater for irrigation purpose

*Email: msunny9887@gmail.com 
(Qadir et al., 2010). Use of contaminated wastewater to irrigate crops and vegetables increases the risk of entry of toxic metal into our food chain. For example, Ahmad et al. (2019) observed $\mathrm{Pb}$ and $\mathrm{Cd}$ contamination in wheat grain up to 0.2 and $1.6 \mathrm{mg} \mathrm{kg}^{-1}$ respectively, due to irrigation with wastewater. Hussain et al. (2019) also observed $\mathrm{Pb}$ and $\mathrm{Cd}$ contamination in different vegetables (carrot, radish, and spinach) irrigated with wastewater.

In human beings, heavy metals cause severe health problems such as $\mathrm{Pb}$ poisoning especially in children and kidney disease due to Cd toxicity (WHO, 1997: Padmavathiamma and Li, 2007; Rehman et al., 2018). Intake of $\mathrm{Pb}$ and $\mathrm{Cd}$ above their permissible limits could leave carcinogenic impacts in human body (Salman et al., 2019). Cadmium and $\mathrm{Pb}$ could easily cause acute and chronic risk even at their lower concentrations, causing renal damage, headache, hypertension and malformation in fetuses (Shi and Chatt, 2014; Zhou et al., 2019). Svetlana et al. (2019) observed that higher levels of $\mathrm{Pb}$ and $\mathrm{Cd}$ caused chronic sinusitis in children. In plants, heavy metals retard shoot and root growth, reduce mineral uptake $(\mathrm{Fe}, \mathrm{Cu}, \mathrm{Zn}$, $\mathrm{Mn}$ ), and stimulate the production of reactive oxygen species $\left(\mathrm{H}_{2} \mathrm{O}_{2}, \mathrm{O}_{2}-\right)$ that damage plasma membrane (Zou et al., 2019). Improper management to dispose-off wastewater can cause ground and/or drinking water contamination with toxic metals, thereby, it is imperative to strictly monitor the wastewater management (Hussain et al., 2019; Rehman et al., 2019).

Recently, much consideration has been paid to various techniques/ approaches in order to remove toxic metals from effluents discharged in to water bodies such as membrane filtration, reverse osmosis, ion exchange, solvent extraction, absorption/adsorption, precipitation and electrochemical treatments (Miretzky et al., 2006; Singh et al., 2012; Liu et al., 2018). But these techniques cover higher cost, technical expertise and are difficult to apply at large scale (Olguin and Sanchez-Galvan, 2012), thereby, phytoremediation is a well-suited technique. It is cost effective, easy to apply, and is environment friendly (Cheng, 2003; Sarwar et al., 2017; Liu et al., 2018). A hyperaccumulator to be used to extract water soluble heavy metals, should have fast growth, ample root system, higher biomass, resistant to higher concentration of metals, and retain higher metal concentration (Garbisu and Alkorta, 2001; Soda et al., 2012; Rev et al., 2017). In this regard, use of different grass species is gaining promising importance due to their tolerance to phytotoxicity, hinder natural succession of weeds, suitable for grazing, bulk biomass, rapid growth and compact root system. Welldeveloped root system in grasses triggers phytostabilization by retarding metal mobility and improves metal uptake and their accumulation in plant body hence make them more exploring phytoremediant agent as compared to shrubs, herbs, and trees (Ghosh et al., 2017). Literature has confirmed the potential of different grass species (Cynodon dactylon L, Chrysopogon zizanioides, Imperata cylindrical) for the uptake of heavy metals like $\mathrm{Pb}$ and $\mathrm{Cd}$ from wastewater and contaminated soil (Pongthornpruek, 2017; Chen et al., 2019; Kiiskila et al., 2019; Zheng et al., 2019).

\begin{tabular}{|c|c|c|c|c|}
\hline Grass species & Origin & Salient feature & $\begin{array}{l}\text { Salt tolerance potential [Root } \\
\text { zone salinity (EC, dS m }{ }^{-1} \text { ) } \\
\text { causing } 50 \% \text { decrease in yield] }\end{array}$ & Reference \\
\hline $\begin{array}{l}\text { Dhab } \\
\text { (Desmostachya } \\
\text { bipinnata) }\end{array}$ & $\begin{array}{l}\text { China, India, } \\
\text { Pakistan and } \\
\text { Africa }\end{array}$ & $\begin{array}{l}\text { C4 perennial grass, } \\
\text { used as fodder source in } \\
\text { dry-saline areas }\end{array}$ & 9.0 & $\begin{array}{l}\text { NIAB (2007); Gulzar } \\
\text { et al. (2007); Ahmad } \\
\text { et al. (2009); Asrar et } \\
\text { al. (2017) }\end{array}$ \\
\hline $\begin{array}{l}\text { Kallar grass } \\
\text { (Leptochloa } \\
\text { fusca) }\end{array}$ & $\begin{array}{l}\text { Australia, now } \\
\text { well adapted to } \\
\text { Pakistan and } \\
\text { India }\end{array}$ & $\begin{array}{l}\text { C4 perennial grass, } \\
\text { used as animal fodder } \\
\text { and reclamation agent } \\
\text { for saline-sodic soils }\end{array}$ & $22.0-14.6$ & $\begin{array}{l}\text { Qureshi et al. (1982); } \\
\text { Ashraf et al. (2012); } \\
\text { Adabnejad et al. } \\
\text { (2015) }\end{array}$ \\
\hline $\begin{array}{l}\text { Para grass } \\
\text { (Brachiaria } \\
\text { mutica) }\end{array}$ & $\begin{array}{l}\text { African } \\
\text { countries }\end{array}$ & $\begin{array}{l}\text { C4 plant, known as } \\
\text { buffalo grass, used as } \\
\text { pasture, fodder }\end{array}$ & Salt tolerant & $\begin{array}{l}\text { Ashraf et al. (2012); } \\
\text { Mohanty and Patra, } \\
\text { (2012) }\end{array}$ \\
\hline $\begin{array}{l}\text { Sporobolus } \\
\text { (Sporobolus } \\
\text { arabicus) }\end{array}$ & & $\begin{array}{l}\text { C4 perennial grass, } \\
\text { used as desalinization } \\
\text { tool for saline-sodic } \\
\text { soils }\end{array}$ & 21.7 & $\begin{array}{l}\text { Ashraf et al. (2012); } \\
\text { Falla et al. (2017); } \\
\text { Yobi et al. }(2017)\end{array}$ \\
\hline
\end{tabular}


Therefore, present experiment was conducted to investigate the growth response of four different salt tolerant grass species in wastewater and to assess the phytoextraction potential of four different salt tolerant grass species for $\mathrm{Pb}$ and $\mathrm{Cd}$ from wastewater in order to identify suitable grass species for the remediation of contaminated wastewater.

\section{Materials and Methods}

\section{Plant material}

Grass species viz. Kallar grass (Leptochloa fusca), Para grass (Brachiaria mutica), Sporobolus (Sporobolus arabicus) and Dhab (Desmostachya bipinnata) were brought from the Biosaline Research Station Pakka Anna, a substation of Nuclear Institute for Agriculture and Biology (NIAB), Faisalabad. The silent features of the grasses are presented in Table 1. Each grass was grown in plastic pots (three plants/cuttings per pot) containing gravel and three liters of wastewater which was aerated manually by placing pots outside on wooden sticks for two hours twice a day (morning and evening). Each grass was grown in three independent pots, representing three replicates. The pots were placed in the greenhouse of NIAB under natural conditions/ photoperiod, with mean temperatures of $23-26{ }^{\circ} \mathrm{C}$ (night-day) and relative humidity of $60-65 \%$. Wastewater was replaced twice a week with its fresh counterpart till plants were harvested after three months. After harvesting root and shoot samples were dried at $70{ }^{\circ} \mathrm{C}$ in oven until constant weight and dry matter was recorded.

Table 2: Characteristics of industrial wastewater used in the experiment

\begin{tabular}{lll}
\hline Parameter & Value & Unit \\
\hline $\mathrm{pH}$ & 7.42 & \\
$\mathrm{SAR}$ & 254 & \\
$\mathrm{EC}$ & 3.57 & $\mathrm{dsm}^{-2}$ \\
$\mathrm{RSC}$ & 7 & $\mathrm{me} \mathrm{L}^{-1}$ \\
$\mathrm{TSS}$ & 3390 & $\mathrm{mg} \mathrm{L}^{-1}$ \\
$\mathrm{CO}_{3}^{-}$ & $\mathrm{ND}$ & $\mathrm{mg} \mathrm{L}^{-1}$ \\
$\mathrm{HCO}_{3}^{-}$ & 17 & $\mathrm{mg} \mathrm{L}^{-1}$ \\
$\mathrm{Na}^{+}$ & 570 & $\mathrm{mg} \mathrm{L}^{-1}$ \\
$\mathrm{~K}^{+}$ & 56 & $\mathrm{mg} \mathrm{L}^{-1}$ \\
$\mathrm{Total}^{-} \mathrm{N}$ & 2.372 & $\mathrm{mg} \mathrm{L}^{-1}$ \\
$\mathrm{NH}_{4}-\mathrm{N}$ & 0.07 & $\mathrm{mg} \mathrm{L}^{-1}$ \\
$\mathrm{NO}_{3}-\mathrm{N}$ & 0.0006 & $\mathrm{mg} \mathrm{L}^{-1}$ \\
Phosphorus & 0.278 & $\mathrm{mg} \mathrm{L}^{-1}$ \\
Organic carbon & 42.3 & $\mathrm{mg} \mathrm{L}^{-1}$ \\
Ca+Mg & 10 & $\mathrm{me} \mathrm{L}^{-1}$ \\
\hline
\end{tabular}

\begin{tabular}{lll}
\hline $\mathrm{Cl}^{-}$ & 20 & $\mathrm{me} \mathrm{L}^{-1}$ \\
$\mathrm{~Pb}$ & 0.92 & $\mathrm{mg} \mathrm{L}^{-1}$ \\
$\mathrm{Cd}$ & 0.03 & $\mathrm{mg} \mathrm{L}^{-1}$ \\
\hline
\end{tabular}

ND*: Not detected

\section{Water quality analysis}

The wastewater used in this study was collected from industrial wastewater collecting system of village 'Chakaira 217 R.B.' Faisalabad, Punjab, Pakistan. The collected wastewater was stored in the plastic tanks once and analyzed for different quality indicators which are presented in Table 2. The $\mathrm{pH}$ was measured by $\mathrm{pH}$ meter (HI-8520, Hanna Instruments, UK), EC and total soluble salts (TSS) by conductivity meter (LF-538 WTW, Germany), carbonates $\left(\mathrm{CO}^{-3}\right)$, bicarbonates $\left(\mathrm{HCO}^{-3}\right)$, chlorides $\left(\mathrm{Cl}^{-}\right)$, calcium $\left(\mathrm{Ca}^{+2}\right)$ and magnesium $\left(\mathrm{Mg}^{+2}\right)$ were determined by titration method as described by Richards (1954). Sodium $\left(\mathrm{Na}^{+}\right)$and potassium $\left(\mathrm{K}^{+}\right)$were determined by Flame Photometer (PFP7-Jenway, UK). Phosphorus was measured by Watanabe and Olsen (1965) method, organic carbon by Riehm and Ulrich (1954) method. Nitrogen $\left(\mathrm{NH}_{4}+-\mathrm{N}, \mathrm{NO}_{3}--\right.$ $\mathrm{N}$, total N) was determined by following Kroon (1993) and Kjeldahl method with some modification. Wastewater was concentrated in water bath and the organic bound $\mathrm{N}$ was digested by adding the mixture of conc. $\mathrm{H}_{2} \mathrm{SO}_{4}, \mathrm{~K}_{2} \mathrm{SO}_{4}$ and Se as catalyst.

\section{Metal concentration, uptake and translocation factor (TF)}

Root and shoot samples were ground and digested following the method described by Wolf (1982). After digestion, extracts of samples were used to determine $\mathrm{Pb}$ and $\mathrm{Cd}$ concentration by atomic absorption spectrometer (AA240FS, Varian, Australia). Shoot metal uptake was calculated by multiplying shoot dry matter with shoot metal concentration:

Shoot metal uptake $(\mu \mathrm{g} / \mathrm{plant})=$ shoot dry matter $(\mathrm{g}) \times$ shoot metal concentration $(\mu \mathrm{g} / \mathrm{g})$

Translocation factor (TF) was calculated by following formula (Soda et al., 2012):

$T F=$ shoot metal concentration" / root metal concentration

\section{Statistical analysis}

Statistical differences among different grass species were assessed by one-way analysis of variance (ANOVA) at $p \leq 0.05$ and least significant difference (LSD) test was used to separate the significant means of treatments using Statistix 8.1. 


\section{Results}

\section{Wastewater characteristics}

Different physicochemical parameters of wastewater
(Table 2) revealed that wastewater contained significant amount of essential plant nutrients (N, P, K, Ca, Mg), organic $\mathrm{C}$ while high levels of $\mathrm{Na}^{+}\left(570 \mathrm{mg} \mathrm{L}^{-1}\right)$, SAR (254), RSC (7 $\left.\mathrm{mg} \mathrm{L}^{-1}\right)$, and TSS (3390 $\left.\mathrm{mg} \mathrm{L}^{-1}\right)$ were recorded. Heavy

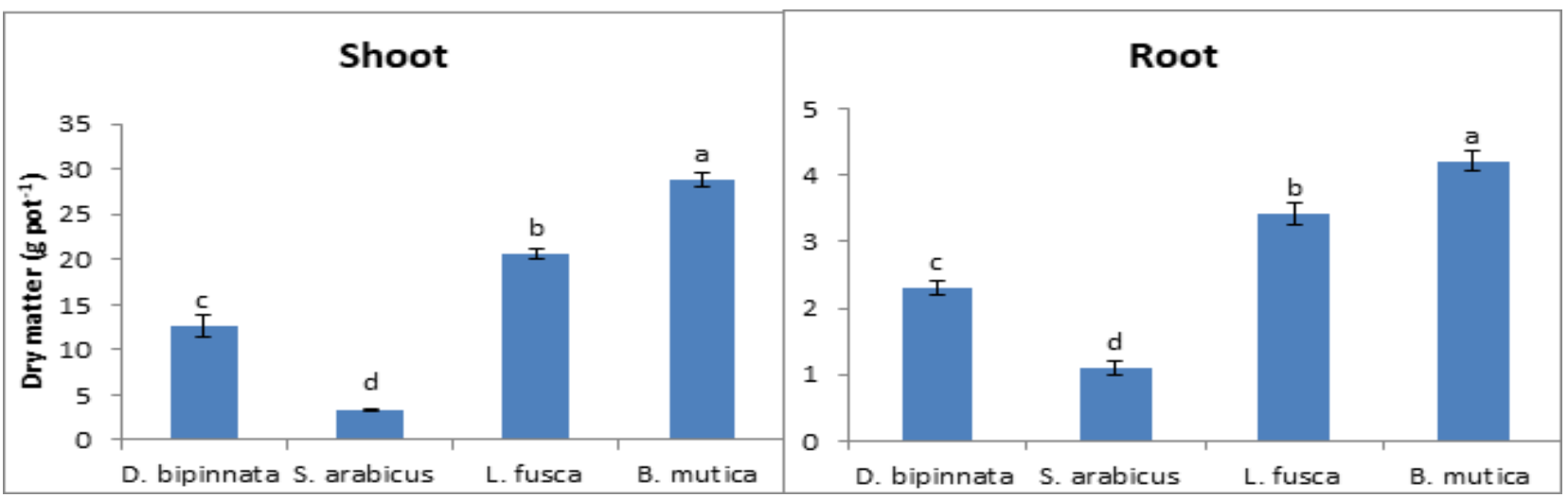

Figure 1: Effect of industrial wastewater on shoot and root dry matter yield of various grasses. Data represent the means of three replicates. The bars sharing similar letters do not differ significantly at $p \leq 0.05$.

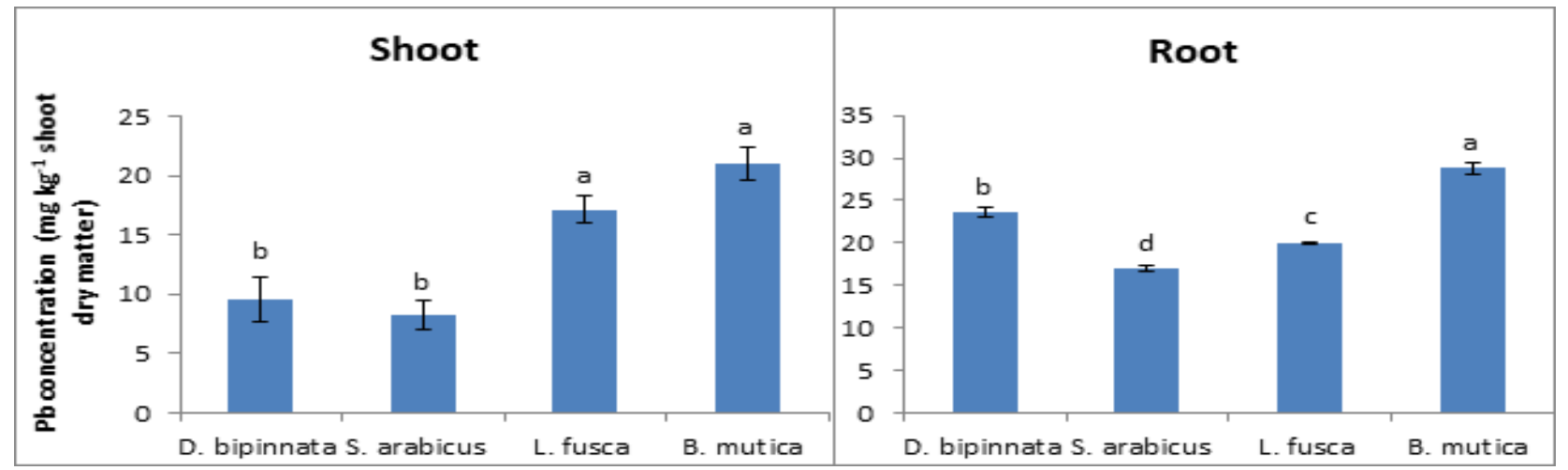

Figure 2: Effect of industrial wastewater on shoot and root $\mathrm{Pb}$ concentration of various grasses. Data represent the means of three replicates. The bars sharing similar letters do not differ significantly at $p \leq 0.05$.

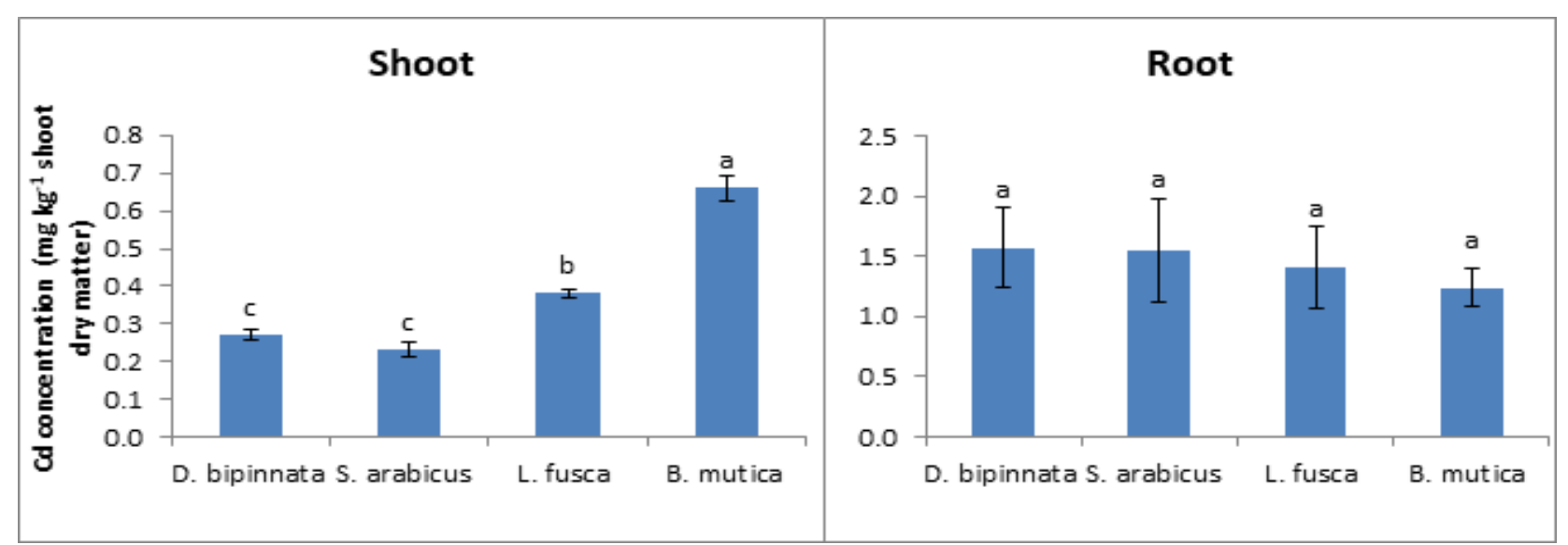

Figure 3: Effect of industrial wastewater on shoot and root Cd concentration of various grasses. Data represent the means of three replicates. The bars sharing similar letters do not differ significantly at $p \leq 0.05$. 
metals $\mathrm{Pb}$ and $\mathrm{Cd}$ were found to be 0.92 and $0.03 \mathrm{mg} \mathrm{L}^{-1}$, respectively.

\section{Dry matter yield}

Results regarding shoot dry matter yield are presented in Figure 1. B. mutica had maximum shoot dry matter yield $\left(28.8 \mathrm{~g} \mathrm{pot}^{-1}\right)$ as compared to other grass species, following L. fusca (20.6 g per pot) and D. bipinnata $\left(12.6 \mathrm{~g} \mathrm{pot}^{-1}\right)$, while the $S$. arabicus showed lowest dry matter yield of 3.4 $\mathrm{g} \mathrm{pot}^{-1}$. Similarly, in case of root dry matter yield (Figure 1), application of Chakaira-wastewater significantly affected the root dry matter of all grass species at $p \leq 0.05$. Root dry matter was observed in the sequence of B. mutica $>$ L. fusca $>$ D. bipinnata $>S$. arabicus ranging between 1.1 to $4.21 \mathrm{~g}$ pot $^{-1}$.

\section{Shoot and Root metal concentration}

Being statistically at par with each other, B. mutica and L. fusca had more $\mathrm{Pb}$ concentration in shoot, i.e. 21.05 and $17.14 \mathrm{mg} \mathrm{kg}^{-1}$ dry weight, respectively, than D. bipinnata and $S$. arabicus with corresponding values of 9.55 and 8.19 $\mathrm{mg} \mathrm{kg}^{-1}$ dry weight, respectively (Figure 2). Data regarding root $\mathrm{Pb}$ concentration (Figure 2) revealed that highest root $\mathrm{Pb}$ concentration was recorded in B. mutica $\left(28.82 \mathrm{mg} \mathrm{kg}^{-1}\right.$ dry weight) while the lowest was in $S$. arabicus $(8.19 \mathrm{mg}$ $\mathrm{kg}^{-1}$ dry weight). Root $\mathrm{Pb}$ concentration in and D. bipinnata and L. fusca was 23.61 and $20.06 \mathrm{mg} \mathrm{kg}^{-1}$ dry weight, respectively. In case of shoot $\mathrm{Cd}$ concentration (Figure 3), high values were recorded for B. mutica $\left(0.66 \mathrm{mg} \mathrm{kg}^{-1}\right.$ dry weight) followed by $L$. fusca $\left(0.38 \mathrm{mg} \mathrm{kg}^{-1}\right.$ dry weight). The $S$. arabicus and D. bipinnata showed lower shoot $\mathrm{Cd}$ concentration, 0.23 and $0.27 \mathrm{mg} \mathrm{kg}{ }^{-1}$ dry weight

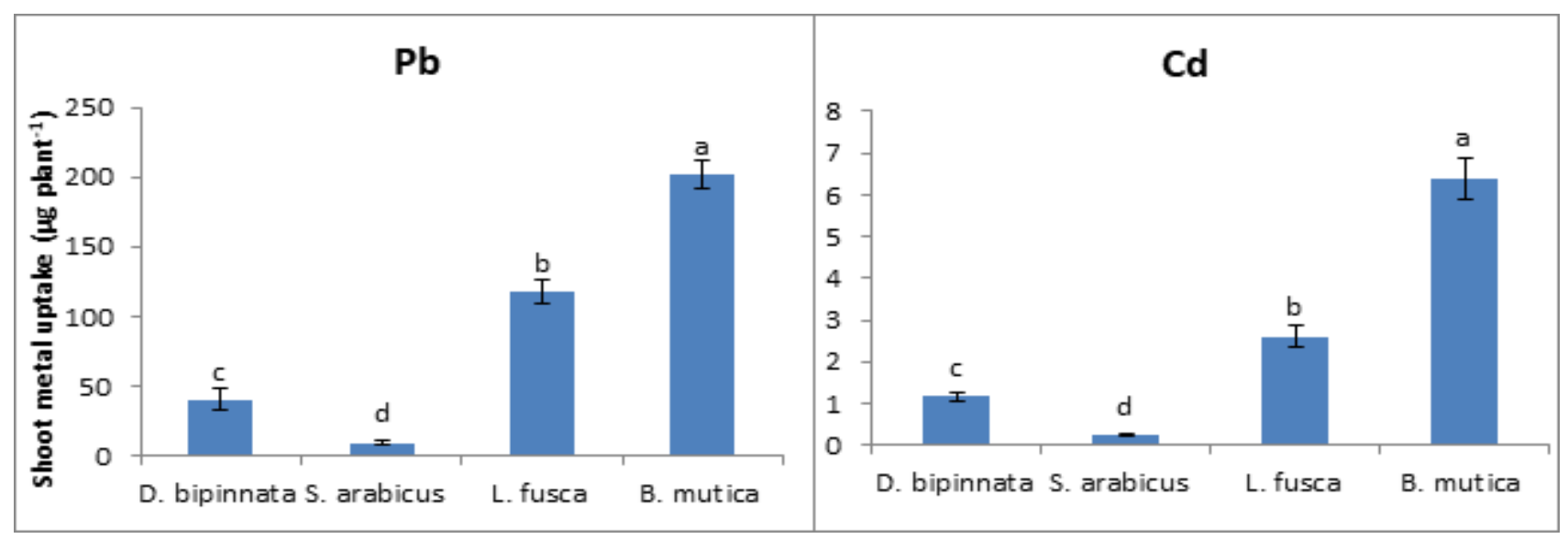

Figure 4: Effect of industrial wastewater on $\mathrm{Pb}$ and $\mathrm{Cd}$ shoot uptake of various grasses. Data represent the means of three replicates. The bars sharing similar letters do not differ significantly at $p \leq 0.05$.

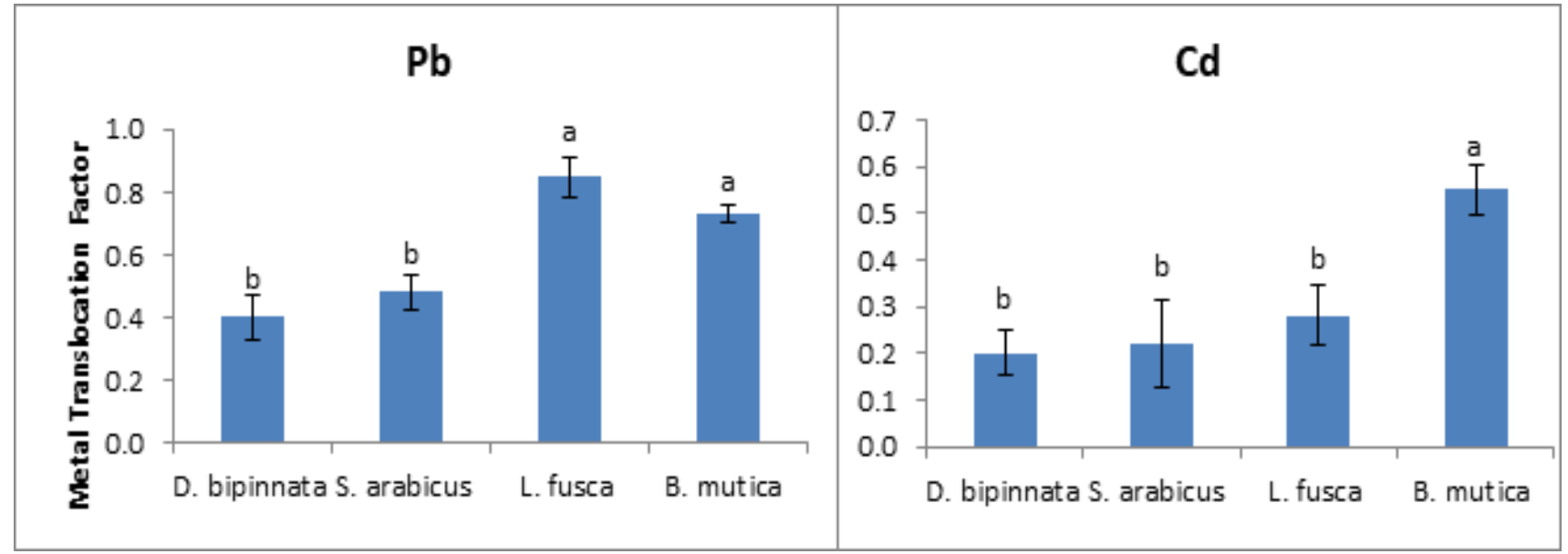

Figure 5: Effect of industrial wastewater on $\mathrm{Pb}$ and $\mathrm{Cd}$ translocation factor (TF) of various grasses. Data represent the means of three replicates. The bars sharing similar letters do not differ significantly at $p \leq 0.05$. 
respectively, with non-significant difference among them. However, no significance difference was observed in root $\mathrm{Cd}$ concentration of different grass species (Figure 3 ) and it ranged from $1.24-1.57 \mathrm{mg} \mathrm{kg}^{-1}$ dry weight.

\section{Metal uptake and Translocation factor}

Shoot metal uptake varied with different grass species and was in the range of 9.4-201.8 and 0.26-6.39 $\mu$ g plant $^{-1}$ for $\mathrm{Pb}$ and $\mathrm{Cd}$ (Figure 4), respectively. Uptake for both the metals by different grass species was in the order $B$. mutica $>$ L. fusca $>$ D. bipinnata $>$ S. arabicus. However, B. mutica indicated better efficiency with significant uptake of $\mathrm{Pb}$ and $\mathrm{Cd}, 201.8$ and $6.39 \mu \mathrm{g}$ plant $^{-1}$ respectively, in comparison to other grass species. The translocation factor (TF) for $\mathrm{Pb}$ and $\mathrm{Cd}$ did not exceed the unity (Figure 5). B. mutica and $L$. fusca gave higher TF-values for $\mathrm{Pb} 0.73$ and 0.85 , respectively, compared to other grasses. Moreover, TF did not differ significantly for $D$. bipinnata, L. fusca and $S$. arabicus except for B. mutica which showed highest TFvalue 0.55 ( $p \leq 0.05)$.

\section{Discussion}

The pollution status is becoming worse especially in the developing countries due to modernization, such as Pakistan where industries share the major portion in water pollution (Sial et al., 2006; Majeed et al., 2018; Kadam et al., 2018; Hussain et al., 2018). These industries are generating over 435 million gallons of sewage and effluents daily (Ijaz et al., 2016). A large quantity of this wastewater is discharged in the outer environment, and farmers near urban areas are likely to use this water for irrigation purpose due to shortage of good quality irrigation water. It contains toxic metals i.e. $\mathrm{Cd}(0.03 \mathrm{mg}$ $\left.\mathrm{L}^{-1}\right)$ and $\mathrm{Pb}\left(0.92 \mathrm{mg} \mathrm{L}^{-1}\right)$ (Table 2). Amount of $\mathrm{Pb}$ present in wastewater was above the permissible limit set by National Environmental Quality Standards (NEQS), Pakistan. Thereby, there is dire need for appropriate treatment of wastewater in order to prevent the entry of toxic metals into food chain.

Growth potential of grasses in wastewater showed variable influence on shoot and root dry biomass of grass species, especially B. mutica indicated good growth which might be due to the presence of organic matter and inorganic mineral ions like $\mathrm{N}, \mathrm{P}, \mathrm{K}, \mathrm{Ca}$, and $\mathrm{Mg}$ in wastewater which are necessary for plant growth and development (Adrover et al., 2012; Rev et al., 2017). The results of present study are consistent to the findings that use of urban wastewater as irrigation enhanced the photosynthesis, growth and dry matter yield of chickpea (Tak et al., 2013). S. arabicus showed least growth potential compared to other grass species which might be due to the suppressive effects of toxic elements $(\mathrm{Cd}, \mathrm{Pb})$ present in the wastewater (Nair et al., 2008; Adrover et al., 2012). These toxic metals may reduce plant growth by inhibiting photosynthesis, respiration and enzymatic activity, decreasing chlorophyll and nitrogen contents, increasing the production of reactive oxygen species, disequilibrium in nutrients, water and hormonal balance of plants (Li et al., 2012; Lou et al., 2017; Akhtar et al., 2018). It was observed that grass species showed variable response regarding accumulation of $\mathrm{Pb}$ and $\mathrm{Cd}$ in roots and shoots in wastewater growth medium. However, the $\mathrm{Pb}$ and $\mathrm{Cd}$ concentration in roots of all grass species was more than shoot. This might be due to negative charges present on root surface capable to bind the metal cations and decrease root to shoot transport (Zhivotovsky et al., 2011). These results are in line with the findings of Roongtanakiat et al. (2007) who found more concentration of heavy metals $(\mathrm{Pb}, \mathrm{Mn}, \mathrm{Cu}, \mathrm{Fe}, \mathrm{Zn})$ in roots as compared to shoot of Vetiveria zizanioides growing in industrial wastewater. Moreover, Silva et al. (2016) also observed high $\mathrm{Cd}$ concentration in roots compared to above ground parts of forage grasses.

Results regarding shoot metal concentration and shoot metal uptake showed that B. mutica had maximum metal concentration $\left(\mathrm{Pb} 21\right.$ and $\mathrm{Cd} 0.66 \mathrm{mg} \mathrm{kg}^{-1}$ dry matter) and uptake $\left(\mathrm{Pb} 201.8\right.$ and $\mathrm{Cd} 6.4 \mu \mathrm{g}$ plant $\left.^{-1}\right)$ followed by $L$. fusca. Good response of B. mutica for uptake and accumulation of heavy metals $(\mathrm{Pb}, \mathrm{Cd})$ could be due to different genetically controlled mechanisms responsible for varying uptake and transportation potential of metal cations from soil/ solution to aerial parts of the plant such as composition and quantity of organic acids released through roots to mobilize/ chelate the metal cations (Hall, 2002; Sarwar et al., 2010; Najafi et al., 2015; Alves et al., 2016). These results are in agreement with our recent study in which B. mutica showed good potential regarding the shoot metal concentration $(\mathrm{Cd}>150$ and $\mathrm{Pb}>1000 \mathrm{mg}$ $\mathrm{kg}^{-1}$ dry matter) and shoot metal uptake ( $\mathrm{Pb} 6000$ and $\mathrm{Cd}$ $1200 \mu \mathrm{g} \mathrm{pot}{ }^{-1}$ ) under contaminated nutrient solution hydroponic culture (Ullah et al., 2019). Mohanty and Patra (2012) observed significant $\mathrm{Cr}$ uptake (i.e. total accumulation rate $8.2 \mathrm{mg} \mathrm{kg}^{-1} \mathrm{day}^{-1}$ and transportation index 6.16) with luxuriant growth and biomass, thereby, suggesting para grass an excellent plant for remediation of heavy metal contaminated wastewater and soil. The TF value refers to the efficiency of plant to transport the metal from root to above ground parts i.e. shoot, leaves. In our experiment, for both metals all grass species showed TF value less than one which shows the lower rate of metal transfer from root to shoot. Similar results were observed by Aran et al. (2017) who observed TF values less than 
one for different heavy metals $(\mathrm{Pb}, \mathrm{Cr}, \mathrm{Ni}, \mathrm{Zn})$ in $L$. laevigatum growing under wastewater.

\section{Conclusion}

It can be concluded on the basis of current findings, among the test grass species that B. mutica showed better efficacy regarding metal transfer, accumulation, and uptake with luxuriant growth or biomass. Thereby, B. mutica could be a better option to filter out the toxic metals from wastewater.

\section{References}

Adabnejad, H, H.R. Kavousi, H. Hamidi and T. Avassolian. 2015. Assessment of the vacuolar $\mathrm{Na}+/ \mathrm{H}+$ antiporter (NHX1) transcriptional changes in Leptochloa fusca $\mathrm{L}$. in response to salt and cadmium stresses. Molecular Biology Research Communications 4: 133-142.

Adrover, M., G. Moya and J. Vadell. 2012. Effect of treated wastewater irrigation on plant growth and biological activity in three soil types. Communications in Soil Science and Plant Analysis 43:1163-1180.

Afzal, M., K. Rehman, G. Shabir, R. Tahseen, A. Ijaz, A.J. Hashmat and H. Brix. 2019. Large scale remediation of oil-contaminated water using floating treatment wetlands. npj Clean Water doi:10.1038/s41545-0180025-7.

Ahmad, F., M.A. Khan, M. Ahmad, M. Zafar, A. Nazir and S.K. Marwat. 2009. Taxonomic studies of grasses and their indigenous uses in the salt range area of Pakistan. African Journal of Biotechnology 8: 231-249.

Ahmad, K., K. Wajid, Z.I. Khan, I. Ugulu, H. Memoona, M, Sana, K. Nawaz, I.S. Malik, H. Bashir and M. Sher. 2019. Evaluation of potential toxic metals accumulation in wheat irrigated with wastewater. Bulletin of Environmental Contamination and Toxicology 102: 822-828.

Akhtar, M.J., S. Ullah, I. Ahmad, A. Rauf, S.M. Nadeem, M.Y. Khan, S. Hussain and L. Bulgariu. 2018. Nickel phytoextraction through bacterial inoculation in Raphanus sativus. Chemosphere 190: 234-242.

Ali, H., E. Khan and I. Ilahi. 2019. Environmental chemistry and ecotoxicology of hazardous heavy metals: Environmental persistence, toxicity, and bioaccumulation. Journal of Chemistry doi.org/10.1155/2019/6730305.

Alves, J.C., A.P. Souza, M.L.A. Porto, R.L.F. Fontes, J. Arruda and L.F. Marques. 2016. Potential of sunflower, castor bean, common buckwheat and vetiver as lead phytoaccumulators. Revista Brasileira de Engenharia Agrícola e Ambiental. 20: 243-249.
Aran, D.S., C.A. Harguinteguy, A. Fernandez-Cirelli and M.L. Pignata. 2017. Phytoextraction of $\mathrm{Pb}, \mathrm{Cr}, \mathrm{Ni}$, and $\mathrm{Zn}$ using the aquatic plant Limnobium laevigatum and its potential use in the treatment of wastewater. Environmental Science and Pollution Research 24:18295-18308.

Ashraf, M.Y., A.R. Awan and K. Mahmood. 2012. Rehabilitation of saline ecosystems through cultivation of salt tolerant plants. Pakistan Journal of Botany 44: 69-75.

Asrar, H., T. Hussaina, S.M.S. Hadi, B. Gul, B.L. Nielsen and M.A. Khan. 2017. Salinity induced changes in light harvesting and carbon assimilating complexes of Desmostachya bipinnata (L.) Staph. Environmental and Experimental Botany 135: 86-95.

Azizullah, A., M.N.K. Khattak, P. Richter and D.P. Hader. 2011. Water pollution in Pakistan and its impact on public health, A review. Environment International 37: 479-497.

Chen, B., S. Tan, Q. Zeng, A. Wang and H. Zheng. 2019. Soil nutrient heterogeneity affects the accumulation and transfer of cadmium in Bermuda grass (Cynodon dactylon (L.) pers.). Chemosphere 221: 342-348.

Cheng, S. 2003. Heavy metals in plants and phytoremediation. Environmental Science and Pollution Research International 10:335-340.

Duffus J. H. 2002. "Heavy metals"-a meaningless term. Pure App. Chemistry: 74: 793-807.

Falla, F., D. Dioufa, D. Fall, N. Bakhouma, B. Thioyea, A. Kanea, C. Ndiayeb, I. Ndoyea and A.M. Bae. 2017. Growth and physiological responses of Sporobolus robustus kunth seedlings to salt stress. Arid Land Research and Management 31: 46-56.

Garbisu, C. and I. Alkorta. 2001. Phytoextraction: A costeffective plant-based technology for the removal of metals from the environment. Bioresource Technology 77: 229-236.

Ghosh, I., M. Ghosh and A. Mukherjee. 2017. doi.org/10.1007/978-3-319-55426-6_7. Remediation of mine tailings and fly ash dumpsites: Role of poaceae family members and aromatic grasses. p.1-50. In: Enhancing cleanup of environmental pollutants. N. Anjum, S. Gill and N. Tuteja. (eds). Springer International Publishing.

Gulzar, S., M. Khan and X. Liu. 2007. Seed germination strategies of Desmostachya bipinnata: a fodder crop for saline soils. Rangeland Ecology and Management 60: 401-407.

Hall, J.L. 2002. Cellular mechanisms for heavy metal detoxification and tolerance. Journal of Experimental Botany 53: 1-11. 
Hussain, A., M. Priyadarshi and S. Dubey. 2019. Experimental study on accumulation of heavy metals in vegetables irrigated with treated wastewater. Applied Water Science 9:122.

Hussain, S., M. Habib-Ur-Rehman, T. Khanam, A. Sheer, Z. Kebin and Y. Jianjun. 2019. Health risk assessment of different heavy metals dissolved in drinking water. International Journal of Environmental Research and Public Health 16: 1737.

Hussain, Z., M. Arslan, M.H. Malik, M. Mohsin, S. Iqbal and M. Afzal. 2018. Treatment of the textile industry effluent in a pilot-scale vertical flow constructed wetland system augmented with bacterial endophytes. Science of the Total Environment 645: 966-973.

Ijaz, A., Z. Iqbal and M. Afzal. 2016. Remediation of sewage and industrial effluent using bacterially assisted floating treatment wetlands vegetated with Typha domingensis. Water Science and Technology 74: 2192-2201.

IWMI (International Water Management Institute), 2003. Confronting the realities of wastewater use in agriculture. Water Policy Briefing 9. IWMI, Colombo, Sri Lanka.

Kadam, S.K., V.V. Chandanshive, N.R. Rane, S.M. Patil, A.R. Gholave, R.V. Khandare, A.R. Bhosale, B.H. Jeon and S.P. Govindwar. 2018. Phytobeds with Fimbristylis dichotoma and Ammannia baccifera for treatment of real textile effluent: An in-situ treatment, anatomical studies and toxicity evaluation. Environmental Research 160: 1-11.

Kiiskila, J.D., D. Sarkar, S. Panja, S.V. Sahi and R. Datta. 2019. Remediation of acid mine drainage-impacted water by vetiver grass (Chrysopogon zizanioides): A multiscale long-term study. Ecological Engineering 129: 97-108.

Kroon, H. 1993. Determination of nitrogen in water: comparison of a continuous-flow method with on-line UV digestion with the original Kjeldahl method. Analytica Chimica Acta 276: 287-293.

Latif, S.A., S. Sharif, S.M. Hossain, M.A. Islam, I.M. Mehedi and M.S. Sultana. 2019. Heavy metal contamination of surface soils in southern part of Bangladesh. Soil and Environment 38(1): 112-118.

Li, H., H. Hao, X. Yang, L. Xiang, F. Zhao, H. Jiang and Z. He. 2012. Purification of refinery wastewater by different perennial grasses growing in a floating bed. Journal of Plant Nutrition 35: 93-110.

Liu, L., W. Li, W. Song, and M. Gou. 2018. Remediation techniques for heavy metal-contaminated soils: Principles and applicability. Science of the Total Environment 63: 206-219.
Lou, Y., P. Zhao, D. Wang, E. Amombo, X. Sun, H. Wang, et al. 2017. Germination, physiological responses and gene expression of tall fescue (Festuca arundinacea Schreb.) growing under $\mathrm{Pb}$ and $\mathrm{Cd}$. PLOS ONE 12: $\mathrm{e} 0169495$.

Majeed, S., S. Rashid, A. Qadir, C. Mackay and F. Hayat. 2018. Spatial patterns of pollutants in water of metropolitan drain in Lahore, Pakistan, using multivariate statistical techniques. Environmental Monitoring and Assessment 190: 128.

Minhas, P.S. and J.S. Samra. 2004. Wastewater use in periurban agriculture: impacts and opportunities. Central Soil Salinity Research Institute, Karnal, India. 75 p.

Miretzky, P., A. Saralegui and A.F. Cirelli. 2006. Simultaneous heavy metal removal mechanism by dead macrophytes. Chemosphere 62: 247-254.

Mitra, A. 2019. Heavy metal status in the lower Gangetic Delta. P. 113-156. In: Estuarine Pollution in the Lower Gangetic Delta. A. Mitra (ed.). Springer, Cham.

Mohanty, M. and H.K. Patra. 2012. Phytoremediation potential of paragrass-an in-situ approach for chromium contaminated soil. Internation Journal of Phytoremediation 14: 796-805.

Mushtaq, J. and R. Batool. 2019. Cr (VI) resistant Bacillus and Acinetobacter isolated from soil of Narran valley. Soil and Environment 38(1): 57-65.

Nair, J., J. Levitan and N. Oyama. 2008. Zinc and copper uptake by silver beet grown in secondary treated effluent. Bioresource Technology 99: 2537-2543.

Najafi, S. and M. Jalali. 2015. Effects of organic acids on cadmium and copper sorption and desorption by two calcareous soils. Environmental Monitoring and Assessment 9: 187-585.

NIAB 2007. Activities at Biosaline Research Station, Pakka Anna. In: Thirty-Five Years of NIAB. Nuclear Institute for Agriculture and Biology (NIAB), Faisalabad, Pakistan.

Olguin, E.J. and G. Sanchez-Galvan. 2012. Heavy metal removal in phytofiltration and phycoremediation: the need to differentiate between bioadsorption and bioaccumulation. New Biotechnology. 30: 3-8.

Padmavathiamma, P.K. and L.Y. Li. 2007. Phytoremediation technology: Hyper-accumulation. metals in plants. Water Air Soil Pollution 184: 105126.

Pongthornpruek, S. 2017. Swine farm wastewater treatment by constructed wetland planted with vetiver grass. Environment and Natural Resources Journal 15: 13-20.

Qadir, M., D. Wichelns, L. Raschid-Sally, P.G. McCornick, P. Drechsel, A. Bahri and P.S. Minhas. 
2010. The challenges of wastewater irrigation in developing countries. Agricultural Water Management. 97: 561-568.

Qureshi, R.H., M. Salim, M. Abdullah and M.G. Pitman. 1982. Diplachne fusca: An Australian salt tolerant grass used in Pakistan agriculture. Journal of Australian Institute and Agriculture Science 48: 195199.

Rai. P.K., S.S. Lee, M. Zhang,Y.F. Tsang and K.H. Kim. 2019. Heavy metals in food crops: Health risks, fate, mechanisms, and management. Environment International 125: 365-385.

Rehman, K., A. Ijaz, M. Arslan and M. Afzal. 2019. Floating treatment wetlands as biological buoyant filters for wastewater reclamation. International Journal of Phytoremediation doi.org/10.1080/15226514.2019.1633253.

Rehman, K., A. Imrana, I. Amina and M. Afzal. 2018. Inoculation with bacteria in floating treatment wetlands positively modulates the phytoremediation of oil field wastewater. Journal of Hazardous Materials 349: 242-251.

Rev, A., B. Toth, A. Solti, G. Sipos and F. Fodor. 2017. Responses of Szarvasi-1 energy grass to sewage sludge treatments in hydroponics. Plant Physiology and Biochemistry 118: 627-633.

Richards, L.A. 1954. U.S. Salinity Laboratory Staff. Diagnosis and Improvement of Saline and Alkali Soils. Agricultural handbook 60. U.S. Dept. of Agriculture, Washington D.C., $160 \mathrm{p}$.

Riehm, H. and B. Ulrich. 1954. Quantitative colorimetrische Bestimmung der organischen Substanz im Boden. Landwirtsch Forsch 6: 173-176.

Roongtanakiat, N., S. Tangruangkiat and R. Meesat. 2007. Utilization of vetiver grass (Vetiveria zizanioides) for removal of heavy metals from industrial wastewaters. Science Asia 33: 397-403.

Salman, S.A., A.A. Asmoay, A. El-Gohary and H. Sabet. 2019. Evaluation of human risks of surface water and groundwater contaminated with $\mathrm{Cd}$ and $\mathrm{Pb}$ in the southern El-Minya Governorate, Egypt. Drinking Water Engineering and Science 12: 23-30.

Sarwar, N., Saifullah, S.S. Malhi, M.H. Zia ${ }^{\mathrm{d}, \mathrm{e}}$, A. Naeem, S. Bibia and G. Farid. 2010. Role of mineral nutrition in minimizing cadmium accumulation by plants. Journal of Science Food and Agriculture 90: 925-937.

Sarwar, N., M. Imran, M.R. Shaheen, W. Ishaque, M.A. Kamran, A. Matloob, A. Rehim and S. Hussain. 2017. Phytoremediation strategies for soils contaminated with heavy metals: Modifications and future perspectives. Chemosphere 171:710-721.
Shi, Y. and A. Chatt. 2014. Simultaneous determination of inorganic, As (III), As (V), Sb (III), Sb(V), and Se (IV) species in natural waters by APDC/MIBK-NAA. Journal of Radioanalytical Nuclear Chemistry 299: 867-877.

Sial, R.A., M.F. Chaudhary, S.T. Abbas, M.I. Latif and A.G. Khan. 2006. Quality of effluents from Hattar Industrial Estate. Journal of Zhejiang University Science B 7: 974-80.

Silvaa, E.B., F.G. Fonsecaa, L.R.F. Alleoni, S.S. Nascimentoa, P.H. Grazziottia and B.O. Nardisa. 2016. Availability and toxicity of cadmium to forage grasses grown in contaminated soil. International Journal of Phytoremediation 18: 847-852.

Singh, D., A. Tiwari and R. Gupta. 2012. Phytoremediation of lead from wastewater using aquatic plants. Journal of Agricultural Technology 8: $1-11$.

Singh, O.V., S. Labana, G. Pandey, R. Budhiraja and R.K. Jain. 2003. Phytoremediation: An overview of metallicion decontamination from soil. Applied Microbiology and Biotechnology 61: 405-412.

Soda, S., T. Hamada, Y. Yamaoka, M. Ike, H. Nakazato, Y. Saeki, T. Kasamatsu and Y. Sakurai. 2012. Constructed wetlands for advanced treatment of wastewater with a complex matrix from a metalprocessing plant: Bioconcentration and translocation factors of various metals in Acorus gramineus and Cyperus alternifolius. Ecological Engineering 39: 6370.

Svetlana, S., A.A. Tinkov and A.V. Skalny. 2019. Hair toxic metal and metalloid levels in children with chronic sinusitis. Journal of Elementology 24: 10911100.

Tak, H.I., O.O. Babalola, M.H. Huyser and A. Inam. 2013. Urban wastewater irrigation and its effect on growth, photosynthesis and yield of chickpea under different doses of potassium. Soil Science and Plant Nutrition 59: 156-167.

Ullah, S., T. Mahmood, Z. Iqbal, A. Naeem, R. Ali and S. Mahmood. 2019. Phytoremediative potential of salttolerant grass species for cadmium and lead under contaminated nutrient solution. International Journal of doi.10.1080/15226514.2019.1594683.

Phytoremediation

Watanabe, F.S. and S.R. Olsen. 1965. Test of ascorbic acid method for determining phosphorus in water and $\mathrm{NaHCO}_{3}$ extract from soils. Soil Science Society of American Journal 29: 677-678.

WHO. 1997. Health and environment in sustainable development. Geneva: WHO. 
Wolf, B. 1982. A comprehensive system of leaf analyses and its use for diagnosing crop nutrient status. Communications in Soil Science and Plant Analysis 13:1035-59.

Yobi, A., K.A. Schlauch, R.L. Tillett, W.C. Yim, C. Espinoza, B.W.M. Wone, J.C. Cushman and M.J. Oliver. 2017. Sporobolus stapfianus: Insights into desiccation tolerance in the resurrection grasses from linking transcriptomics to metabolomics. BMC Plant Biology 17:67.

Zheng, H., Z. Zhang, X. Xing, T. Hu, C. Qu, W. Chen and J. Zhang. 2019. Potentially toxic metals in soil and dominant plants from tonglushan $\mathrm{Cu}-\mathrm{Fe}$ deposit, Central China. Bulletin of Environmental Contamination and Toxicology 102: 92-97.
Zhivotovsky, O.P., J.A. Kuzovkina, C.P. Schulthess, T. Morris, D. Pettinelli, D. and M. Ge. 2011. Hydroponic screening of willows (Salix L.) for lead tolerance and accumulation. International Journal of Phytoremediation 13: 75-94.

Zhou, M, W. Tian, J. Zhang, X. Chen, Y. Wu and S. Wang. 2019. A rapid on-site analysis method for the simultaneous extraction and determination of $\mathrm{Pb}^{2+}$ and $\mathrm{Cd}^{2+}$ in cereals. RSC Advances doi: $10.1039 / \mathrm{c} 9 \mathrm{ra} 05587 \mathrm{~h}$.

Zou, J., X. Shang, C. Li, J. Ouyang, B. Li and X. Liu. 2019. Effects of cadmium on mineral metabolism and antioxidant enzyme activities in Salix matsudana Koidz. Polish Journal of Environmental Studies 28: 989-999. 